\title{
P267: Current aspects of acquired infection in maternity Issaka Gazobi hospital - Niamey, Niger
}

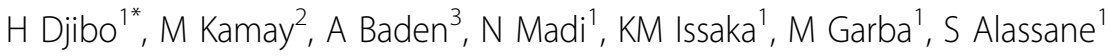 \\ From 2nd International Conference on Prevention and Infection Control (ICPIC 2013) \\ Geneva, Switzerland. 25-28 June 2013
}

\section{Objectives}

This document is the result of a study of 1 November 2010 to 30 March 2011 on nosocomial infections at the Maternity Issaka Gazobi.

\section{Methods}

This prospective survey covered a total of 139 patients of Obstetrics.

\section{Results}

After analyzing the data, it appears that: The prevalence of nosocomial infections was $7.2 \%$, including $0.7 \%$ of endometritis, urinary tract infection $0.7 \%$ and $5.8 \%$ of surgical site infection distributed as follows: $3.5 \%$ and $2.2 \%$ of deep and superficial infections respectively. Nearly eight out of 10 patients were from the urban community of Niamey and 70\% of infected patients are housewives. Prolonged urinary catheterization, as well as antibiotic misuse were the main contributing factors. In newborns, the prevalence of nosocomial infections was $5 \%$ of which $1.4 \%$ were skin infections and $3.6 \%$ eye infections, no umbilical cord infection was recorded. The mortality rate of newborns was $14.4 \%$. Nosocomial infections are and remain a public health problem.

\section{Conclusion}

This is what we contribute to formulate recommendations for the administrative and health authorities and for healthcare workers.

\section{Competing interests}

None declared.

\section{Author details}

'Department of Public Health, Faculty of Health Sciences, University of Niamey, Niamey, Niger. ${ }^{2}$ Health Sector Control Unit against STI / HIV / AIDS, Ministry of Public Health, Niamey, Niger. ${ }^{3}$ Niamey National Hospital, Niamey, Niger.

Published: 20 June 2013

doi:10.1186/2047-2994-2-S1-P267

Cite this article as: Djibo et al:: P267: Current aspects of acquired

infection in maternity Issaka Gazobi hospital - Niamey, Niger.

Antimicrobial Resistance and Infection Control 2013 2(Suppl 1):P267.
${ }^{1}$ Department of Public Health, Faculty of Health Sciences, University of Niamey, Niamey, Niger

Full list of author information is available at the end of the article
Submit your next manuscript to BioMed Central and take full advantage of:

- Convenient online submission

- Thorough peer review

- No space constraints or color figure charges

- Immediate publication on acceptance

- Inclusion in PubMed, CAS, Scopus and Google Scholar

- Research which is freely available for redistribution 